\title{
Dampak Keharmonisan Keluarga dan Pola Asuh Orangtuaterhadap Prestasi Belajar Siswa SDN 113 Pana
}

\author{
Irman Syarif $^{1}$, Priska De Yanti Hoar Taek ${ }^{2}$ \\ ${ }^{1}$ PGSD, FKIP, Universitas Muhammadiyah Enrekang, 91711, Indonesia \\ ${ }^{2}$ Pendidikan Sosiologi, FKIP, Universitas Muhammadiyah Kupang, 85111, Indonesia \\ email:irmanstkip@gmail.com
}

\begin{abstract}
Abstrak
Tujuan penelitian untuk mengetahui dampak keharmonisan keluarga terhadap presatsi belajar siswa dan untuk mengetahui faktor-faktor yang mempengaruhi keharmonisan keluarga terhadap prestasi belajar siswa di SDN 113 Pana. Metode yang digunakan adalah metode kualitatif yang dimaksudkan untuk menemukan, mengembangkan dan mengkaji kebenaran. Subjek penelitian ini adalah siswa, guru dan orangtua murid di SDN 113 Pana. Teknik pengumpulan data pada penelitian ini adalah observasi, wawancara dan dokumentasi. Hasil penelitian ini menunjukan bahwa terdapat dampak keharmonisan keluarga terhadap prestasi belajar. Artinya, semakin tinggi keharmonisan keluarga, maka semakin tinggi pula prestasi belajar siswa. Dalam penelitian, ini juga dapat dilihat faktor- faktor yang mempengaruhi prestasi belajar siswa yaitu faktor internal (intelegensi, perhatian, sikap, motivasi, kesiapan dan minat) dan faktor ekternal (keluarga, dan sekolah).
\end{abstract}

Kata Kunci: keharmonisan keluarga, prestasi belajar

\begin{abstract}
The research purposes to find out the impact of family harmony on the learning achievement and to find out the factors influence family harmony on the learning achievement of SDN 113 Pana. The method used is a qualitative to find develop and study the truth. The subjects of this study were studenst, teachers and parents of SDN 113 Pana. Data collection techniques in this study were interview, observations and documentation. The results of this study indicate that there is an impact of family harmony on learning achievement. This means that the higher harmony of the family, the higher of student's learning achievement. The study also can be seen the factors that influence student learning achievement, namely internal factors (delegation, attention, attitude, motivation, readiness and interest) and external factors (family and school).
\end{abstract}

Keywords: family harmony, learning achievement

\section{Pendahuluan}

Keluarga yang harmonis adalah keluarga yang rukun, damai, bahagia, penuh cinta dan kasih serta jarang terjadi konflik dalam keluarga tersebut. Terciptanya keluarga yang harmonis jika istri taat kepada suami dan suami sayang kepada istri dan berlandaskan kepada norma-norma agama, serta menjalankan tugas dan tanggung jawab masing-masing, saling menghormati, saling menghargai, saling mencintai, saling memahami, saling mendukung, dan saling menjaga lisan (Aulia, 2015; Syahrul, 2020; Rahmawati, Zahrawati, Pathuddin, \& Khatimah, 2019). 
Keluarga harmonis di Pana memberikan tempat bagi setiap anggota keluarga, oleh karena itu, jika ada keluarga yang sering terjadi perselisihan dan pertengkaran, maka suasana keluarga tidak menyenangkan. Pasangan suami istri harus mampu bersikap fleksibel dalam menghadapi konflik rumah tangga tersebut. Dalam keluarga harmonis di Pana, setiap anggota keluarga berusaha menyelesaikan masalah dengan kepala dingin dan mencari penyelesaian terbaik dari setiap permasalahan. Hubungan antara anggota keluarga menentukan keharmonisan dalam sebuah keluarga serta masadepan anak dalam keluarga. Juga akan berdampak pada pendidikan anak. Apabila dalam suatu keluarga tidak memiliki hubungan erat, maka antar anggota keluarga tersebut tidak ada lagi rasa saling memiliki dan kebersamaan hilang (Azzahrah, 2016; Syahrul \& Wardana, 2017).

Semua keluarga mengharapkan akan terciptanya hubungan yang harmonis dalam rumah tangga. Dengan kehadiran anak, itu akan menjadi kebanggaan dan sumber kebahagiaan. keberhasilan dan kesuksesan dalam mengasuh serta mendidik anak untuk menjadi manusia yang bermamfaat bagi nusa dan bangsa merupakan harapan bagi setiap orangtua. Namun seiring dengan berjalannya waktu tidaklah semua pasangan suami istri mampu memelihara keharmonisan dan mendidik anak-anaknya dengan baik (Isminayah \& Supandi, 2016; Syahrul \& Datuk, 2018). Hal ini sangat mempengaruhi tingkat prestasi anak di sekolah.

Perkembangan psikologi anak di Sekolah Dasar harus sejalan dan selaras dengan aspek perkembangan lainnya yaitu psikis, serta moral dan sosial mengingat perkembangan keterampilan berpikir, bertindak dan pengaruh sosial yang sudah mulai kompleks. Daya konsentrasi anak mulai tumbuh saat berada di tingkat Sekolah Dasar. Selama masa itu, mereka juga mulai mampu menilai diri mereka sendiri, menilai keadaan dan suasana di sekitar lingkungan dan mampu membandingkan dengan orang lain. Anak-anak yang lebih mudah menggunakan perbandingan sosial (social comparison) terutama untuk norma-norma sosial dan kesesuaian jenis-jenis tingkah laku tertentu. Pada saat anak-anak tumbuh semakin lanjut, mereka cenderung menggunakan perbandingan sosial untuk mengevaluasi dan menilai kemampuan mereka sendiri (Syarif \& Rahmat, 2018).

Kehadiran orangtua dalam mengasuh anak sangat membantu mengembangkan karakter dan psikologis anak terhadap adaptasi lingkungannya di lingkungan masyarakat maupun di lingkungan sekolah (Syahrul, 2018). Pola asuh orang tua yang baik akan memberikan kesempatan pada anak untuk mengembangkan seluruh aspek kognitif, apektif dan psikomotorik, sehingga prestasi anak di sekolah lebih meningkat (Junaidi, 2015; Suparman, 2018). Oleh karena itu, keharmonisan keluarga yang baik akan berpengaruh kepada tingkat pola asuh yang baik pula kepada anak, sehingga mampu memberikan stimulus yang positif pada tahap perkembangan belajar anak di sekolah.

Tenaga pendidik atau guru-guru di sekolah Dasar SDN 113 Pana, ketika mendapatkan seorang siswa yang bermasalah dengan keluarganya atau orangtuanya maka guru-guru akan memberikan nasehat kepada siswa tersebut. Apabila siswa tersebut berkelahi di sekolah, maka Kepala Sekolah akan memanggil orangtua siswa agar dapat memberi nasehat kepada siswa bukan hanya nasehat yang diberikan kepada siswa tersebut, tetapi juga sanksi atas masalah yang terjadi. Dengan demikian, siswa yang mendapat hukuman tersebut akan merasa tersingkir dan malu, dan dapat menyebabkan siswa tersebut acuh tak acuh untuk ke sekolah dan bahkan ingin berhenti untuk bersekolah. Dengan demikian masalah tersebut bukan hanya selesai di sekolah tetapi dapat mempengaruhi hubungan keluarga dan bisa dikatakan keluarga tersebut hilang akan keharmonisan 
(Khadifa \& Sugihen, 2018; Wicaksono, 2019).

Banyak siswa di sekolah SDN 113 Pana yang awalnya berpamitan kepada orangtua untuk berangkat ke sekolah, tetapi pihak sekolah menelpon ke orangtua bahwa anaknya tidak masuk sekolah. Siswa juga mengeluh dalam keluarganya banyak masalah, sehingga siswa tidak merasa nyaman saat berada di rumah karena suasana rumah selalu ada permasalahan-permasalahan yang dihadapi dalam keluarganya tersebut. Atas dasar hal tersebut, siswa lebih banyak menghabiskan waktu untuk bermain bersama teman-temanya di luar rumah. Kondisi seperti itu juga berdampak pada kehidupan sosial anak terutama dalam interaksi atau sosialisasi dengan teman di sekolah (Khusniah, 2017; I. Setiawan, 2017; Zahrawati, 2020).

Orangtua siswa menganggap bahwa setelah anak mendapatkan pendidikan di sekolah maka hak dan kewajiban orangtua untuk memberikan pendidikan kepada anaknya sudah tanggung jawab pihak sekolah, berhasil atau tidaknya anak dalam belajar, tinggi atau rendahnya prestasi belajarnya sudah menjadi tanggung jawab sekolah. Keluarga yang harmonis dapat memberikan perasaan tenang, aman dan timbul rasa takut dalam melakukan sesuatu hak kepada setiap individu. Sesuatu keluarga dikatakan harmonis apabila setiap harinya diliputi suasana saling mencintai, saling menghargai, saling mempercayai keluarga (Marjanah, 2016; D. Setiawan, 2017).

Berdasarkan masalah di atas, maka fokus penelitian ini adalah siswa SDN 113 Pana yang memiliki masalah keluarga yang berdampak pada prestasi di sekolah. Tujuan penelitian ini adalah untuk mengetahui bagaimana dampak keharmonisan keluarga dan pola asuh orangtua terhadap prestasi belajar siswa dan faktor apa sajakah yang mempengaruhi prestasi belajar siswa SDN 113 Pana.

\section{Metode Penelitian}

Penelitian ini adalah penelitian kualitatif yang dilakukan secara mendalam dan intensif untuk mengungkapkan bagaimana hubungan keharmonisan keluarga dengan prestasi belajar siswa SDN 113 Pana di Kabupaten Enrekang. Penelitian mengambil beberapa informan di sekolah tersebut dengan menggunakan purposive sampling, rincianya sebagai berikut: guru, siswa, dan orangtua siswa SDN 113 Pana. Teknik pengumpulan data yang digunakan peneliti dalam mendapatkan data di lapangan adalah dengan menggunakan teknik observasi dalam mengamati dinamika perilaku siswa dalam proses pembelajaran di sekolah tersebut dan juga lingkungan keluarga. Melakukan wawancara pada siswa, orangtua, dan guru. Dokumentasi adalah suatu cara yang digunakan untuk memperoleh data dan informasi dalam bentuk buku, arsip, dokumen, tulisan angka dan gambar yang berupa keterangan yang dapat mendukung penelitian. Analisis data dimulai dari data reduction (reduksi data), data display (penyajian data), dan conclusion drawing (penarikan kesimpulan ) (Miles \& Hubberman, 2009).

\section{Pembahasan}

\section{Dampak Keharmonisan Keluarga Terhadap Prestasi Belajar Siswa}

Salah satu dampak keharmonisan keluarga dan pola asuh orangtua terhadap prestasi belajar adalah mengakibatkan peran di antara ayah dan ibu yang tidak bisa berkolaborasi dengan anak secara efektif dalam mendidik anak. Anak kurang belajar karena tidak ada keharmonisan dalam keluarga. Ketidakmampuan memecahkan masalah membuat siswa kurang efektif untuk belajar akhinya prestasinya menurun. Keluarga kurang berperan dalam menjalankan fungsinya sebagai 
keluarga akhirnya membawa berbagai dampak yang buruk bagi anak. Dampak yang terjadi di dalam keluarga yaitu keadaan sosial ekonominya rendah. Banyak yang mengalami kesulitan dalam memenuhi kebutuhan sekolah anak.

Untuk mengetahui lebih jauh dampak keharmonisan keluarga dan pola asuh orangtua terhadap prestasi belajar, maka peneliti melakukan wawancara terhadap orangtua murid, siswa dan Guru. Adapun hasil wawancara dengan orangtua siswa, sebagai berikut "harapan saya sebagai orangtua, saya harus memotivasi agar harus tekun belajar, agar kedepanya bisa berguna bagi kedua orang tuanya" (Rifin , senin 27 april 2019 ). Dari hasil wawancara yang peneliti lakukan terhadap Ibu Rifin (orangtua murid), maka dapat memaknai bahwa dalam proses belajar, orangtua selalu memotivasi anaknya agar dapat belajar dengan tekun. Dari wawancara tersebut dapat dikatakan bahwa dari motivasi yang dilakukan oleh orang tua, siswa secara tidak langsung mempunyai dorongan yang kuat dalam belajar, sehingga dapat berpengaruh terhadap prestasi belajarnya.

Untuk mengetahui dampak keharomisan keluarga dan pola asuh orangtua terhadap prestasi belajar siswa, maka selanjutnya peneliti melakukan wawancara terhadap siswa. Adapun hasil wawancaranya sebagai berikut "saya sangat berminat belajar di sekolah dan saya senang karena banyak pengetahuan yang saya dapatkan di sekolah tersebut" (Upi , senin 28 april 2019). Dari hasil wawancara dapat dilihat bahwa siswa mempunyai semangat dan minat untuk bersekolah karena dapat memberikan pengetahuan terhadap dirinya. Selain itu dalam pembelajaran yang paling penting adalah bagaimana minat dan niat para siswa dalam belajar di sekolah karena minat dan niat merupakan hal yang paling mendasar. Jika dalam pribadi siswa sendiri tidak mempunyai niat, maka yang terjadi adalah eksistensinya di sekolah dapat terganggu.

Untuk mengetahui dampak keharmonisan keluarga terhadap prestasi belajar siswa, maka selanjutnya peneliti melakukan wawancara terhadap guru. Adapun hasil wawancaranya sebagai berikut "pendapat saya terhadap prestasi belajar siswa di kelas adalah memiliki kemampuan yang bervariasi, cerdas, sedang, kurang" (Saskia , jumat 24 April 2019 ). Berdasarkan pendapat guru diatas, dapat diketahui bahwa prestasi belajar siswa sangat bervariasi dari cerdas, sedang dan kurang. Tentunya dapat dari proses belajar para peserta didik di sekolah. Lebih jauh dijelaskan bahwa terdapat faktor-faktor lain yang mempengaruhi tingkat prestasi belajar, yaitu semangat belajar siswanya yang kurang, kemalasan dari siswa itu sendiri (sekolah dan mengerjakan tugas sekolah) dan juga motivasi yang harus terus dipupuk oleh siswa itu sendiri, orangtua, sahabat dan juga gurunya sendiri.

Dukungan keluarga dan orangtua berperan penting dan tanggung jawab untuk mendorong anak serta menyekolakannya di lembaga pendidikan dengan harapan nantinya lebih mampu untuk mengembangkan minat dalam meningkatkan prestasi belajar. Walaupun anak sudah masuk sekolah, tetapi harapan masih digantungkan kepada keluarga untuk memberikan pendidikan dan suasana sejuk dan menyenangkan belajar anak di dalam rumah. Dengan adanya dukungan keluarga yang harmonis siswa dapat meningkatkan aktivitasnya dalam belajar agar prestasi belajar anak di sekolah akan tercapai dengan baik. Namun jika keluarganya tidak harmonis dan kurang dukungan dari keluarga bisa saja mengakibatkan siswa kurang dalam kegiatan belajar dan akan mempengaruhi prestasi anak. Sebagian orangtua yang beranggapan bahwa keadaan di dalam rumah dan kondisi keluarga tidak mempunyai peranan yang begitu besar terhadap prestasi belajar anak dalam belajar di sekolah. Dari uraian di atas, maka dapat ditarik kesimpulan bahwa ada dampak keharmonisan keluarga terhadap prestasi belajar siswa di SDN 113 Pana kecamatan Alla kabupaten Enrekang. Hal 
ini bisa dibuktikan dengan hasil data temuan yang didapat pada proses penelitian.

\section{Faktor-Faktor yang Mempengaruhi Prestasi Belajar Siswa}

Dalam proses pembelajaran di kelas, banyak faktor yang perlu diperhatikan oleh seorang tenaga pendidik dalam proses pembelajaran di kelas setiap hari. Faktor-faktor tersebut akan sangat mempengaruhi proses kegiatan belajar mengajar di sekolah. Untuk mengetahui lebih jauh tentang faktor-faktor tersebut, maka dapat dilihat pada dua faktor, yaitu internal dan eksternal. Faktor internal adalah faktor yang terjadi dalam diri peserta didik itu sendiri yang bersifat lahiriah atau secara biologis. Adapun bebrapa klasifikasi dalam faktor tersebut yaitu: Pertama, intelegensi adalah kemampuan untuk bertindak dengan mendapatkan suatu tujuan untuk berfikir secara rasional, dan untuk berhubungan dengan lingkungan di sekitarnya secara memuaskan. Untuk lebih jauh, dapat kita simak hasil wawancara dengan siswa sebagai berikut,

Dalam pemahaman materi yang diajarkan oleh guru, semua tergantung materi dari mata pelajaran yang sedang dibawakan, semisalkan ada pelajaran berarti saya tidak paham sama sekali, dikarenakan matematika bukan pelajaran yang saya sukai dan memang sangat sulit sekali (Rifki, senin 28 april 2019).

Dari kutipan wawancara di atas, diketahui bahwa siswa hanya mau belajar atau paham jika itu sesuai dengan materi yang sukai, ini menandakan bahwa faktor intelegensi punya pengaruh besar dalam pemahaman siswa terhadap sebuah proses pembelajaran dalam kelas. Dari uraian di atas, maka dapat disimpulkan bahwa intelegnsi merupakan faktor pendukung yang mempengaruhi prestasi belajar siswa.

Kedua, perhatian merupakan keaktifan jiwa yang tinggi untuk menjamin belajar yang baik maka siswa harus mempunyai perhatian tehadap apa yang disampaikan oleh Guru dalam pelajaranya. Jika pelajaran tidak menjadi perhatian siswa, maka timbulah kebosanan, sehingga siswa tidak senang dengan pelajaran yang disampaikan oleh guru. Untuk menggali lebih jauh, dapat dilihat pada uraian percakapan berikut, "dalam kegiatan belajar mengajar, saya selalu memperhatikan dengan serius apa yang diajarkan oleh guru, hanya saja dalam keseriusan saya dalam belajar, kadang diganggu oleh teman-teman kelas saya" (Rifki, senin 28 April 2019). Hasil wawancara responden di atas bahwa dalam kegiatan belajar, siswa memperhatikan apa yang disampaikan oleh guru, tetapi kadang diganggu oleh teman belajarnya sehingga berpengaruh pada pemahaman sebuah materi yang sedang dipelajari. Selain itu, dapat diketahui bahwa dalam proses kegiatan belajar mengajar, perhatian siswa juga merupakan hal yang sangat berpengaruh pada prestasi belajar siswa.

Ketiga, kesiapan siswa dalam proses belajar mengajar, sangat mempengaruhi prestasi belajar siswa, dengan demikian prestasi belajar siswa dapat berdampak positif bila siswa mempunyai kesiapan dalam menerima suatu mata pelajaran dengan baik. Untuk lebih jauh dapat diuraikan pada hasil wawancara sebagai berikut,

Sebelum proses kegiatan belajar, saya selalu mempersiapkan diri secara jasmaniah dan rohani sebelum melakukan kegiatan belajar mengajar di sekolah. Tapi ada beberapa momen saya sangat tidak siap, tapi takut dimarahi oleh orang tua, saya akhirnya sekolah (Rifki, Senin 28 April 2019). 
Dari hasil wawancara di atas, dapat dilihat bahwa sebelum sekolah siswa sudah mempersiapkan diri dengan baik (jasmani-rohani) sebelum kegiatan belajar mengajar berlangsung, sehingga proses kegiatan belajar mengajar (KBM) berjalan dengan baik. Dari penegasan di atas, maka dapat dikatakan bahwa kesiapan seorang dalam melakukan pembelajaran merupakan hal yang sangat penting dalam mempengaruhi prestasi belajarnya.

Keempat, motivasi merupakan penggerak yang mengaktifkan siswa untuk melibatkan diri siswa dalam menimbulkan kegiatan belajar, yang menjamin keberlangsungan dari kegiatan belajar. Motivasi mempunyai peranan penting dalam mencapai prestasi belajar. Lebih lanjut, dapat dilihat pada hasil wawancara sebagai berikut "saya selalu mempunyai motivasi kuat dalam hal belajar, entah itu dari diri saya sendiri maupun motivasi dari orang-orang terdekat saya" (Rifki, Senin 28 April 2019). Hasil wawancara ini dapat dikatakan bahwa siswa mempunyai motivasi yang kuat dalam kegiatan belajar mengajar, entah motivasi dari dalam dirinya maupun dari orang-orang terdekatnya. Selain itu, maka dapat disimpulkan bahwa, motivasi adalah hal yang berpengaruh pada prestasi belajar siswa dikarenakan perannya yang sangat penting dalam proses Kegiatan Belajar Mengajar.

Kelima, minat sangat besar pengaruhnya terhadap prestasi belajar siswa. Minat siswa cenderung untuk memperhatikan dan memegang beberapa kegiatan yang diamati oleh siswa dengan cara rasa senang dalam belajar. Seseorang yang didorong oleh minat dan merasa senang dalam belajar dapat memperoleh prestasi belajar yang optimal. Oleh karena itu, guru perlu membangkitkan minat belajar, agar siswa dapat berprestasi dengan baik dan lebih mendalam permasalahan pada siswa, dapat dilihat pada hasil wawancara berikut ini "dalam belajar saya mempunyai minat, tapi kadang-kadang juga tidak. Semua tergantung guru dan juga materi pelajaran yang dibawakan" (Rifki, 28 April 2019). Dari uraian ini, dapat dikatakan bahwa minat belajar siswa sangat variatif, tergantung dari guru dan juga materi pembelajaran yang sedang diajarkan. Hal ini ingin memberikan penegasan bahwa dalam proses pembelajaran minat merupakan hal yang penting dalam kegiatan pembelajaran, sehingga dari minat belajar dari para siswa akan dapat berpengaruh pada prestasi belajar mereka di sekolah tersebut.

Faktor eksternal adalah faktor dari luar yang mempengaruhi pribadi/individu itu sendiri, faktor tersebut dalam kaitanya dengan proses pembelajaran terdapat dua hal yang sangat berpengaruh terhadap peserta didik yaitu, faktor keluarga dan faktor sekolah. Lebih jauh lagi, dapat dilihat pada pembahasan berikut ini. Pertama, faktor keluarga turut mempengaruhi perkembangan prestasi belajar siswa. Pendidikan yang pertama dapat diperoleh dalam keluarga. Jadi keluarga merupakan salah-satu sumber bagi anak untuk belajar. Pelajaran yang diperoleh anak dari rumah tidak baik, di luar lingkungan keluarga menjadi nakal. Pendidikan informal dan formal memerlukan kerjasama antara orangtua anak dengan sekolah anaknya orangtua juga harus menunjukan kerjasama dalam cara anak belajar di rumah. Lebih jauh lagi, dapat dilihat pada, hasil wawancara yang peneliti lakukan terhadap orangtua "kami selaku orang tua selalu memberikan motivasi dan dorongan agar anak kami terus semangat dalam belajar, apapun masalah harus tetap sekolah dikarenakan kita orang susah" (Buik, 27 April 2019 ).

Hasil wawancara di atas, dapat diketahui bahwa untuk urusan sekolah dan belajar, selaku orangtua, mereka selalu mondorong dan memotivasi anaknya agar tetap sekolah dan belajar dengan baik. Dari wawancara tersebut, dapat dikatakan bahwa dorongan orang tua kepada anaknya merupakan faktor yang penting kaitanya dengan semangat belajar anaknya di sekolah, sehingga 
presatsi belajar anaknya dapat diraih. Kedua, faktor sekolah menyangkut proses pembelajaran yang diterima seseorang dengan bantuan guru. Metode pembelajaran yang diberikan oleh guru sangat menentukan bagaimana anak dapat belajar mandiri dengan baik. Guru yang baik merupakan guru yang menguasai kelas dan memiliki kemampuan dalam menggunakan metode pemebelajaran yang tepat sehingga anak bisa mengerti pelajaran yang diberikan oleh guru tersebut. Jika guru salah menggunakan metode, maka siswa tersebut tidak mengerti dan tidak mendapat prestasi dengan baik. Selanjutnya, dapat dilihat pada hasil wawancara guru (mewakili sekolah) sebagai berikut,

Kami sebagai guru dan mewakili sekolah, kami selalu memberikan apa yang kami bisa agar kegiatan anak di sekolah berjalan dengan baik, sesuai dengan ketentuan berlaku. Hal ini kami lakukan agar para siswa dapat belajar dengan baik dan nyaman, dan dapat lulus tepat waktu (Klau, Jumat 24 April 2019).

Dari hasil wawancara di atas, dapat diketahui bahwa sebagai seorang guru mereka akan memberikan segala kemampuan yang mereka miliki agar kegiatan belajar mengajar anak di sekolah berjalan dengan baik dan dapat memberikan efek terhadap siswa. Dapat juga disimpulkan bahwa sekolah menjadi faktor yang penting dalam prestasi anak.

\section{Kesimpulan}

Penelitian ini bertujuan untuk melihat dampak keharmonisan keluarga dan pola asuh orangtua terhadap prestasi belajar siswa SDN 113 Pana. Hasil penelitian ini menunjukan bahwa keharmonisan keluarga berdampak kepada pola asuh yang baik kepada anak sehingga terhadap prestasi belajar siswa SDN 113 Pana. Artinya, semakin tinggi keharmonisan keluarga maka semakin baik pula pola asuh orangtua terhadap anak. Hal ini memberi dampak pada prestasi belajar siswa di sekolah. Dalam penelitian ini juga dapat dilihat 2 faktor yang memberi dampak pada prestasi belajar siswa yaitu faktor internal (intelegensi, perhatian, sikap, motivasi, kesiapan dan minat) dan faktor eksternal (keluarga dan sekolah).

\section{Referensi}

Aulia, A. (2015, July 29). Hubungan antara Keharmonisan Keluarga dengan Prestasi Belajar Siswa di SMP Muhammadiyah 4 Banjarmasin, [Skripsi]. Retrieved September 30, 2020, from http://idr.uin-antasari.ac.id/701/

Azzahrah, S. H. (2016, July 1). Hubungan Antara Keharmonisan Keluarga dengan Prestasi Belajar Siswa di MTsN Banjar Selatan 1. Retrieved September 30, 2020, from https://idr.uinantasari.ac.id/5709/

Isminayah, A., \& Supandi. (2016). Relasi Tingkat Keharmonisan Keluarga dengan Konsep Diri Remaja. al-Balagh: Jurnal Dakwah dan Komunikasi, 1(2), 233-248. https://doi.org/10.22515/balagh.v1i2.354

Junaidi, A. (2015). Pengaruh Tingkat Keharmonisan Keluarga terhadap Prestasi Belajar Siswa Bidang Studi Akidah Akhlak Di MI. Asy-Syafi'iyah Klampisan Tejo Mojoagung Jombang Tahun Pelajaran 2014/2015 (Other, Universitas Pesantren Tinggi Darul Ulum). Universitas Pesantren Tinggi Darul Ulum. Retrieved from http://eprints.unipdu.ac.id/112/

Khadifa, L., \& Sugihen, B. T. (2018). Hubungan Antara Keharmonisan Keluarga dan Kehadiran Belajar Siswa di Sekolah Menengah Atas (SMA) Negeri 5 Kota Banda Aceh. Jurnal Ilmiah 
Mahasiswa Fakultas Ilmu Sosial \& Ilmu Politik, 3(1). Retrieved from http://www.jim.unsyiah.ac.id/FISIP/article/view/6368

Khusniah, D. (2017). Pengaruh keharmonisan keluarga dan kepribadian terhadap prestasi belajar peserta didik di SMK Islam Ahmad Yani Ngantang Kabupaten Malang [Media Cetak]. $\begin{array}{llll}\text { Retrieved } & \text { September } & 30, & 2020,\end{array}$ http://library.unisma.ac.id/slims_unisma/index.php?p=show_detail\&id=25490

Marjanah, R. N. (2016). Pengaruh Keharmonisan Keluarga dan Pola Asuh Orangtua terhadap Prestasi Belajar Siswa Kelas IV SDN Dabin II Kecamatan Tegalrejo Kabupaten Magelang (Other, Universitas Negeri Semarang). Universitas Negeri Semarang. Retrieved from https://lib.unnes.ac.id/29335/

Miles, M. B., \& Hubberman, A. (2009). Michael. Analisis Data Kualitatif, Buku Sumber Tentang Metode-Metode Baru. Penerjemah Tjetje Rohendi). UI Press, Jakarta.

Rahmawati, Zahrawati, F., Pathuddin, H., \& Khatimah, K. (2019). Reviving Gender Awarenes Membangun Kembali Semangat Pembebasan dan Kesetaraan Gender. Parepare: IAIN Parepare Nusantara Press.

Setiawan, D. (2017). Hubungan Keharmonisan Keluarga dengan Prestasi Belajar Siswa Kelas Viii di Sekolah Menengah Pertama Negeri 1 Sentolo Tahun Ajaran 2016/2017. Prodi Bimbingan Dan Konseling Universitas PGRI Yogyakarta. Retrieved from http://repository.upy.ac.id/1725/

Setiawan, I. (2017, November 16). Pengaruh keharmonisan keluarga Terhadap prestasi belajar peserta didik (study korelasi di smp 2 pgri ciputat, tahun ajaran 2016-2017) [Other]. Retrieved September 30, 2020, from http://eprints.unpam.ac.id/3442/

Suparman, K. G. (2018). Hubungan persepsi siswa tentang keharmonisan keluarga dengan prestasi belajar mereka pada mata pelajaran PAI materi Salat Jumat di sekolah: Penelitian terhadap siswa di kelas VII SMP Karya Budi Bandung (Diploma, UIN Sunan Gunung Djati Bandung). UIN Sunan Gunung Djati Bandung. Retrieved from http://digilib.uinsgd.ac.id/13171/

Syahrul, S. (2018). Kritik Ideologi Pendidikan Karakter dalam Masyarakat Demokrasi di Indonesia. Seminar Nasional Pendidikan Dan Kewarganegaraan IV, O(0), 58-67. Retrieved from http://seminar.umpo.ac.id/index.php/SEMNASPPKN/article/view/158

Syahrul, S. (2020). Menanamkan Kemuhammadiyaan Pada Mahasiswa Non-Muslim Melalui Pendidikan Multikultural di Universitas Muhammadiyah Kupang. EDUKASI: Jurnal Penelitian Pendidikan Agama Dan Keagamaan, 18(2). https://doi.org/10.32729/edukasi.v18i2.643

Syahrul, S., \& Datuk, A. (2018). Perilaku Sosial Anak Penjual Koran di Kota Kupang Dalam Mempertahankan Eksistensinya di Sekolah. DIMENSIA: Jurnal Kajian Sosiologi, 7(2), 6882. Retrieved from https://journal.uny.ac.id/index.php/dimensia/article/view/32651

Syahrul, S., \& Wardana, A. (2017). Analisis kebijakan pendidikan untuk anak jalanan di Kota Yogyakarta. Harmoni Sosial: Jurnal Pendidikan IPS, 4(2), 117-130. https://doi.org/10.21831/hsjpi.v4i2.10388 
Syarif, I., \& Rahmat, R. (2018). PENERAPAN MODEL BRAIN-BASED LEARNING TERHADAP PENINGKATAN KARAKTER PESERTA DIDIK KELAS II SEKOLAH DASAR. Edumaspul - Jurnal Pendidikan, 2(2), 87-90. https://doi.org/10.33487/edumaspul.v2i2.13

Wicaksono, N. B. (2019). Hubungan Keharmonisan Keluarga dan Regulasi Diri terhadap Prestasi Belajar pada Siswa SMA (Other, UNIKA Soegijapranata Semarang). UNIKA Soegijapranata Semarang. Retrieved from http://repository.unika.ac.id/19372/

Zahrawati, F. (2020). Pembebasan Jerat Feminisasi Kemiskinan. AL MA'ARIEF: Jurnal Pendidikan Sosial Dan Budaya, 2(1), 170-177. 